Jurnal Warna : Jurnal Pendidikan Dan Pembelajaran Anak Usia dini. September 2017. Vol 02. No. 02

\title{
PENGARUH MEDIA FLASH CARD TERHADAP PERKEMBANGAN BAHASA ANAK KELOMPOK B DI TK NURUS SA'ADAH 03 KECAMATAN LEDOKOMBO KABUPATEN JEMBER
}

\author{
I Made Hartawan \\ IKIP PGRI Jember \\ (hartawanmade51@gmail.com)
}

\begin{abstract}
Abstrct
Teachers can carry out their duties and responsibilities well if they can deliver students until the learning objectives that have been assigned these roles require teachers to have the ability and skills in the learning process such as mastery of teaching methods, learning strategies, communicating. One method that is expected to improve the ability of children in developing the language is the use of Flash cards or picture cards.

Subjects in this study were students of group B TK Nurus Sa'adah 03 District Ledokombo Jember District. The method used is purposive sampling. Which respondents function through the method of observation. In analyzing this data, as free variable is playing Falsh card, while the dependent variable is language development. Thus it can be seen that the working hypothesis received is the Influence of Flash Card Media on Language Development of children B TK Nurus Sa'adah 03 District Ledokombo Jember District. From the results of the researchers at the time of data collection, that the phenomenon in detail can be well understood.
\end{abstract}

Keywords: Flash Card Media, Language Developmen

\section{PENDAHULUAN}

Undang-undang RI nomor 20 tahun 2003 tentang Sisdiknas pasal 28 ayat 3 menyatakan bahwa Taman Kanak-Kanak (TK) merupakan pendidikan anak usia Dini pada jalur pendidikan formal, yang bertujuan membantu anak didik mengembangkan berbagai potensi baik psikis, fisik, yang meliputi moral dan nilai agama, sosial, kemandirian ,kognitif, bahasa, fisik motorik dan siap memasuki sekolah dasar. Taman Kanak-Kanak menjadi penting karenan pada usia 0-6 tahun merupakan masa peka dan hanya datang sekali yang memungkinkan semua potensi anak baik mental dan kecerdasannya dapat berkembang secara optimal (Debdiknas: 2009) Kurikulum Taman Kanak-Kanak dilaksanakan untuk membantu anak didik mengembangkan berbagai potensi perkembangan yang ada dalam diri anak.

Pendidikan merupakan tujuan untuk mencapai keberhasilan dan kesuksesan 
Jurnal Warna : Jurnal Pendidikan Dan Pembelajaran Anak Usia dini. September 2017. Vol 02. No. 02

suatu bangsa. Dalam program pendidikan diperlukan peran guru dalam proses pembelajaran agar tercapai tujuan pendidikan. Untuk menciptakan pembelajaran yang berkualitas yang patut diperhatikan adalah alat atau media dalam pembelajaran.

Sejalan dengan perkembangan zaman, media pembelajaran sudah tidak lagi dipandang sebagai alat bantu belaka bagi guru untuk mengajar, tetapi lebih sebagai alat bantu belaka bagi guru untuk mengajar tetapi lebih sebagai alat penyalur pesan dari pemberi pesan (anak didik). Media pembelajaran tentu sangat di perlukan bagi pendidikan di Taman Kanak- kanak, hal ini karena anak usia dini pemikirannya lebih obyektif.

Salah satu pengembangan kemampuan bahasa anak usia dini adalah pengenalan terhadap huruf sebagai bekal kesiapan membaca pada jenjang pendidikan lebih lanjut.

Menurut Montessori dan Hainstock (dalam Dhieni, dkk:5.3) anak usia dini 4-5 tahun sudah bisa dikenalkan membaca dan menulis permulaan. Bahkan pengenalan membaca dan menulis dirancang dengan sebuah permainan yang unik dan menyenangkan bagi anak usia dini. Kegiatan membaca pada kelompok TK B dimulai dengan mengenal huruf yang disesuaikan tingkat perkembangan anak usia dini di kelompok B.

Menurut Doman (dalam Indrayanti, 2010: 6) Mengemukakan jika ingin mengajarkan anak agar bisa membaca yaitu dengan memberikan tuliasan ataupun awalan huruf yang sering anak temui di sekitar anak. Dengan kata lain, mengajarkan anak mengenalkan kata yang bermakna dan sudah diketahui langsung. Oleh karena itu kemampuan anak membaca diawali dengan mengenal huruf dan disertai dengan metode dan strategi pembelajaran yang menyenangkan dan unik bagi anak. Untuk itu diperlukan alat untuk membantu penyampaian materi pengenalan huruf yang menarik bagi anak. Misalnya dengan mediamedia yang unik dan menarik seperti media flash card. Dengan media flash card, huruf yang digabungkan dapat dibuat semenarik mungkin yang didukung dengan gambar-gambar yang menarik sehingga anak ingin belajar mencobanya. Untuk menentukan materi pendidikan didalam pendidikan yang tergantung dua syarat yaitu: Alat mencapai tujuan, Struktur individualitas anak/peserta didik. 
Jurnal Warna : Jurnal Pendidikan Dan Pembelajaran Anak Usia dini. September 2017. Vol 02. No. 02

Kedua syarat ini diawali oleh UU PP nomer 4 tahun 1990. Media/alat yang dipakai dalam proses untuk mencapai tujuan berdasarkan pola filsafah bangsa Indonesia. Media Flash Card ini erat kaitannya dengan saran dan prasarana baik berupa benda, situasi lingkungan, maupun kegiatan-kegiatan yang dengan sengaja ditampilkan oleh pendidik untuk mencapai tujuan sementara maupun tujuan akhir pendidikan.

Menyenangkan dan menimbulkan kerinduan pada anak, pada suasana pempelajaran yang dijalankan. Bila suasana belajar mengajar itu terjadi, bukan tidak mungkin anak mencapai prestasi yang tinggi.

Berdasarkan uraian diatas maka penulis ingin mengetahui pengaruh Media Flash Card terhadap perkembangan bahasa anak. Sebagaimana tercantum dalam UU no 20 tahun 2003 tentang system pendidikan nasional pasal 28. Bahwa orang tua dan masyarakat juga harus terlibat dalam upaya melaksanakan pendidikan yang bermutu, karena pada dasarnya antara sekolah, orang tua dan masyarakat terjalin pengaruh timbal balik yang tak dapat dipisahkan. Dalam perkembangan bahasa anak yang sesuai dengan norma. Masa usia taman kanak-kanak adalah masa dimana anak bisa dikembangkan dari lima unsur perkembangan dan masa ini anak sangan mudah untuk dikembangkan.

Oleh karena itu guru TK yang berperan sebagai fasilitator dalam penegembangan potensi tersebut diharapkan untuk dapat meningkatkan mutu dan kualitas perkembangan berbahasa anak dengan menggunakan media pembelajaran yaitu media Flash Card, sehingga guru dapat menjalankan peranya dengan baik.

Glenn Doman (dalam fatoni, 2009:12-30) menyatakan bahwa flash card adalah kartu gambar yang efektif untuk mengingat dan menghafal lebih cepat karena pada dasarnya untuk membantu anak belajar mengingat dan menghafal. Karena tujuan ini melatih kemampuan kognitif untuk mengingat gambar dan kata, sehingga kemampuan berbahasa dapat ditingkatkan sejak usia dini.

Mengenal jenis gambar-gambar pada flash card di kelompokkan antara lain: Seri bintang, Buah, Transprotasi, Pakaian, Warna, Bentuk, angka, Huruf. Mengingat besarnya perkembangan bahasa bagi kehidupan anak maka perlu di kembangkan pada anak didik sejak usia dini adapun kegiatan sajian 
Jurnal Warna : Jurnal Pendidikan Dan Pembelajaran Anak Usia dini. September 2017. Vol 02. No. 02

dan orientasi pada kemampuan yang di harapkan dapat di capai dari tema-tema yang akan di bahas. Berdasarkan latar belakang tersebut diatas maka melakukan penelitian sejauh mana pengaruh Media Flash Card terhadap Perkembangan Bahasa Anak Kelompok B TK Nurus Sa'adah 03 Kecamatan Ledokombo Kabupaten Jember.

\section{METODE}

Penelitian ini menggunakan jenis penelitian kualitatif deskriftif. Penelitian kualitatif adalah penelitian yang dimaksudkan untuk mengumpulkan informasi mengenai status suatu gejala yang ada, yaitu keadaan gejala menurut apa adanya saat penelitian di lakukan. Dalam klasifikasi ini, penelitian tentang Kegunaan Media Flash Card untuk meningkatkan Perkembangan Bahasa Anak Kelompok B TK Nurus Sa'adah 03 Kecamatan Ledokombo Kabupaten Jember dapat dikategorikan penelitian kualitatif deskriftif. Dalam penelitian ini menggunakan teknik pengumpulan data dengan cara observasi. Adapun yang menjadi objek observasi adalah perkembangan bahasa anak kelompok B yang berjumlah 50 anak di TK Nurus Sa'adah 03 Kecamatan Ledokombo Kabupaten Jember
Analisis data kualitatif adalah bersifat induktif. Dalam proses menganalisis data yang telah diperoleh dilakukan beberapa tahapan diantaranya Reduksi data, Penyajian data dan kesimpulan

\section{HASIL DAN PEMBAHASAN}

Banyak cara untuk merangsang perkembangan bahasa anak usia dini. Sesuai dengan tujuan penelitian adalah untuk meneliti pengaruh Media Flash Card terhadap perkembangan bahasa.

Dari hasil peneitian bahwa pengaruh media flash card terhadap perkembangan bahasa anak sangat baik. Karena dalam proses bermain secara tidak langsung melibatkan indera pendengaran, mulut untuk berbicara serta melafalkan kata. Sehingga dengan menggunakan media flash card secara tidak langsung dapat mempengaruhi kemampuan perkembangan bahasa anak usia dini.

Dalam Badudu (1989) menyatakan bahwa bahasa adalah alat komunikasi antara anggota masyarakat untuk menyatakan pikiran, perasaan dan keinginannya. Bahasa sebagai suatu lambang bunyi yang biasanya digunakan masyarakat dalam rangka untuk bekerja sama, berinteraksi diri. Berbahasa berarti menggunakan bahasa berdasarkan 
Jurnal Warna : Jurnal Pendidikan Dan Pembelajaran Anak Usia dini. September 2017. Vol 02. No. 02

pengetahuan individu tentang adat dan sopan santun.

Hasil observasi bahwa media flash card adalah alat bantu guru untuk anak belajar dengan bermain, karena media flash card jenisnya bermacam-macam yaitu kartu gambar buah, binatang, huruf, angka, dll. Media flash card mudah sekali untuk di guanakan dan guru dapat membuatnya sendiri tanpa membeli dengan mahal-mahal. Media flash card sangat menarik untuk anak-anak, karena anak dapat merepon dan belajarnya lebih aktif, dari bukti hasil belajar anak-anak dapat berkembang dengan baik sekali. Anak-anak mudah mengingat huruf, gambar, angka yang ada di media flash card. Anak dapat menyebutkan 2 kartu gambar, 3 kartu gambar binatang dengan benar. Dengan adanya media flash card anak-anak dapat belajar dengan hasil yang baik, karena flash card adalah kartu belajar yang efektif untuk mengingat dan menghafal tiga kali lebih cepat.

\section{Hasil Wawancara}

a) Wawancara dengan Siswa

Hasil wawancara anak didik bahwa dia sangat tertarik sekali dengan kartu gambar (Media flash card) dan sangat senang kalau bermain kartu gambar dengan teman-temannya. Ada juga yang mengatakan kartu gambarnya sangat bermacam-macam, ada gambar huruf, angka, binatang, warna. Ibu guru mengajari huruf, binatang dll. Bermain kartu menurut anak didik permainan yang sangat menyenangkan karena dia suka bermain. Anak didk dapat menyebutkan gambar yang ada di media flash card. Menyebutkan huruf a sampai z dan angkaangka sudah baik sekali, mengulang kembali kata "Nanas, nangka, apel juga sudah bisa. Menirukan kalimat yang di sampaikan oleh ibu guru, contoh ibu pergi ke pasar membeli sayur.

b) Wawancara dengan Guru

Hasil wawancara dengan gurun anak didiknya banyak yang tertarik dengan media flash card dan muridnya dengan mudah dapat memainkannya selain caranya yang mudah dan media flash card juga menarik, selain angka dan huruf juga ada gambar-gambarnya yang bagus anak-anak tertaarik. Dengan adanya media flas card muridnya dapat dengan mudah menyebut angka, huruf dan dapat meniru kalimat, juga menambah kosa kata dalam komunikasi sehari-hari. Dalam pengenalan gambar anak-anak sangat merespon dari pertanyaan dari ibu guru juga lebih mudah untuk memahaminya. Pada intinya media Flash card mempermudah guru dalam mengajar, 
Jurnal Warna : Jurnal Pendidikan Dan Pembelajaran Anak Usia dini. September 2017. Vol 02. No. 02

karena daya respon an keaktifan muridnya dalam mengajar lebih meningkat.

Hasil wawancara dengan dalam proses belajar mengajar media flash card sangat membantu, karena media flash card yang sangat menarik untuk bermain sambil belajar. Anak-anak sangat merespon sekali waktu ibu guru mengenalkan kartu gambar yang bermacam-macam, yaitu ada gambar binatang, huruf, angka, dll. Media flash card ternyata sangat mudah sekali untuk di mainkan oleh anak-anak selain itu media flash card juga sangat mudah untuk membuatnya, karena bahan yang di buatnya dapat kita gunakan dari bahan bekas dan guru tidak harus membelinya dengan mahal-mahal. Penggunaan media flash card yang guru kenalkan contoh mengenalkan huruf, guru mengenalkan tiga huruf saja dan di ucapkan dengan lantang/keras kemudian mengulanginya. Setelah itu anak-anak bisa diajak bermain atau berlomba sesuai aturan gurunya. Selain memperdalam kemampuan kognitif juga melatih kemampuan fisik motoriknya. Media flash card sangat bermanfaat sekali utuk anak-anak karena dapat mengembangkan kognitif serta dapat mengembangkan bahasa anak. Anak-anak dapat menirukan kalimat yang di sampaikan oleh guru juga kosa katanya. Media flash card yang sangat praktis, gampang di ingat oleh anak-anak dan juga menyenangkan.

Hasil wawancara dengan anak didiknya sangat tertarik dengan media flash card dan dapat memainkannya karena media flash card lebih mudah anak-anak untuk belajar dan mudah di ingat. Muridnya yang masih kelompok B menurut ibu aisyah sangat mudah sekali untuk menggunakan media flash card karena anak tertarik dengan kartu gambar yang di kenalkan oleh ibu gurunya. Muridnya bisa menirukan huruf-huruf, kata dan kalimat yang di sampaikan oleh ibu gurunya. Anak-anak merespon dari pertanyaan ibu guru karena menurut ibu aisyah media flash card sangat menarik dan rasa ingin tahu anak-anak sangat besar sekali. Setelah anak diajak bermain dengan kartu gambar yang di mainkan oleh anak-anak, besoknya anak-anak minta bermain kartu gambar lagi. Hasil perkembangan bahasa anak sangat baik sekali karena hasil dari media flash card. Hasil belajar anak sangat baik, anak-anak lebih aktif dan semangat. Semoga media flash card ini dapat di kembangkan dan bermanfaat untuk anak-anak.

c) Wawancara dengan Orang Tua

Hasil wawancara dengananak didik, anaknya bisa berbicara dengan baik setelah anaknya masuk sekolah, yang awalnya 
Jurnal Warna : Jurnal Pendidikan Dan Pembelajaran Anak Usia dini. September 2017. Vol 02. No. 02

anaknya belum bisa menyebutkan huruf R,

L, k sekarang sudah bisa. Menyebutkan kata "Aku" saja dulu tidak bisa di ucapnya "Atu" dan mengucapkan kalimat saja tidak pernah sempurna contoh " Aku sudah selesai belajar" faisal bilangnya "Aku udah lesai berajar". Perkembangan putranranya setelah masuk sekolah sangat berkembang sekali. Anaknya mulai mempunyai rasa tanggung jawab dengan tugas yang di berikan oleh ibu guru untuk mengerjakan tugas di rumah dia langsung mengerjakannya. Semangat belajarnya sangat tinggi dan kalau di rumah suka menirukan gurunya mengajar. Kadangkadang bermain dengan dengan temannya sukanya bermain sekolah-sekolahan, untuk mengajari teman- temannya. Orang tuanya melihat anaknya bermain dengan temannya dan apa yang di ajarkan oleh anaknya betul, kemudian orang tua anak didik menanyakan perkembangan anaknya di sekolah kepada gurunya. Gurunya memuji sekali kalau anak didik di sekolahnya aktif, belajarnya baik dan dapat mengikuti kegiatan belajar yang ada di sekolah. Kemudian menceritakan kebiasaan di rumah kalau suka bermain sekolahsekolahan dan menjadi gurunya. Ternyata media yang di gunakan oleh guru sangat merespon anak-anak dan menyenangkan sekali.
Hasil wawancara dengan orang tua anak didik lainya ternyata tidak jauh berbeda hasil dari sekolah yang di ajarkan oleh gurunya sangat baik sekali.Karena sudah bisa membaca dengan lancar tanpa orang tuanya mengeleskan putra - putrinya di tempat bimbingan belajar. Kebiasaan anaknya jika ada tulisan di televisi, di Koran atau di ajak jalan-jalan, dia membaca setiap melihat ada tulisan. menurut orang tuanya sangat kritis kalau melihat sesuatu yang menurut dia belum tahu, maka akan tanya sampai jawabannya jelas. Ternyata yang terjadi dengan anak didik sangat merespon dengan pertanyaan dan utuk mengemukakan pendapatnya juga sudah bisa. Orang tua sangat senang sekali putra-putrinya dapat melaksanakan perintah sederhana, contohnya risa pernah di suruh membelikan sabun mandi dan sabun cuci ternyata dia sudah bisa. Menurut ketiga orang tua tersebut tersebut bahwa anaknya sebelum sekolah nangisan, pemalu, komunikasi tidak lancar dan kalau berbicara masih kurang baik, kata-katanya sering salah dan menirukan kalimat tidak pernah lengkap. Dari komunikasi dengan orang tua dan orang lain, bisa berbicara dengan baik dan kalimatnya baik, dapat mengemukakan pendapatnya. Perkembangan bahasanya juga baik sekali. 
Jurnal Warna : Jurnal Pendidikan Dan Pembelajaran Anak Usia dini. September 2017. Vol 02. No. 02

2. Hasil Observasi

a).Media Flash Card

Hasil obsevasi bahwa media flash card adalah alat bantu guru untuk anak belajar dengan bermain, karena media flash card jenisnya bermacam-macam yaitu kartu gambar buah, binatang, huruf, angka, dll. Media flash card mudah sekali untuk di guanakan dan guru dapat membuatnya sendiri tanpa membeli dengan mahalmahal. Media flash card sangat menarik untuk anak-anak, karena anak dapat merepon dan belajarnya lebih aktif, dari bukti hasil belajar anak-anak dapat berkembang dengan baik sekali. Anakanak mudah mengingat huruf, gambar, angka yang ada di media flash card. Anak dapat menyebutkan 2 kartu gambar, 3 kartu gambar binatang dengan benar. Dengan adanya media flash card anak-anak dapat belajar dengan hasil yang baik, karena flash card adalah kartu gambar yang menarik dan unik dalam hal mengingat dan menghafal tiga kali lebih cepat.

b). Perkembangan Bahasa

Hasil observasi perkembangangan bahasa, proses pembelajaran di taman kanak-kanak (TK) memerlukan suatu metode dan cara tersendiri dalam pencapaian perkembangan bahasa anak. Hal ini mendorong motivasi belajar anak, meningkatkan efektifitas, menambah pengetahuan dan mendorong terjadinya interaksi langsung antara murid dengan guru dan linkungannya. Perkembangan kemampuan berbahasa bagi anak usia dini bertujuan agar anak mampu berkomunikasi secara lancar dengan lingkungannya di sekitarnya yaitu teman sebaya, teman bermain, orang dewasa, baik yang di sekolah, di rumah maupun dengan tetangga di sekitar tempat tinggalnya. Maka hasil obsevasi perkembangan bahasa anak baik. Kosa kata : Anak dapat menyebutkan katakata dengan jelas, dapat menyebut nama benda yang di perlihatkan dengan benar dan mengulang kembali kosa kata yang baru di dengar juga baik. Melaksanakan 23 perintah sederhana, menirukan kembali 3-4 urutan kata dan menirukan kalimat yang di sampaikan juga bisa. Mengemukakan pendapat sederhana dan merespon terhadap pertanyaan juga baik.

3. Hasil Analisis Data

a). Wawancara dan observasi anak

Hasil wawancara bahwa dia sangat tertarik sekali dengan kartu gambar anak didik sangat senang kalau bermain kartu gambar dengan teman-temannya. Menurut anak didik kartu gambarbermacam-macam, ada gambar huruf, angka, binatang, warna. Ibu guru mengajari huruf,binatang dll. Bermain kartu menurut risa dan faisal permainan yang sangat menyenangkan 
Jurnal Warna : Jurnal Pendidikan Dan Pembelajaran Anak Usia dini. September 2017. Vol 02. No. 02

karena dia suka bermain. Faisal, Risa dan Dhika dapat menyebutkan gambar yang ada di media flash card. Menyebutkan huruf a sampai z dan angka-angka sudah baik sekali.

Hasil observasi Media flash card sangat menarik untuk anak-anak, karena anak dapat merepon dan belajarnya lebih aktif, dari bukti hasil belajar anak-anak dapat berkembang dengan baik sekali. Anak-anak mudah mengingat huruf, gambar, angka yang ada di media flash card. Anak dapat menyebutkan 2 kartu gambar, 3 kartu gambar binatang dengan benar. Dengan adanya media flash card anak-anak dapat belajar dengan hasil yang baik.

Hasil wawancara dengan anak dan observasi di atas dapat di simpulkan bahwa Media flash card adalah kartu gambar yang menarik, mudah dimainkan sehingga anak dapat merespon dan belajarnya lebih aktif.

b). Wawancara dan observasi guru

Hasil wawancara anak didik sangat tertarik dengan media flash card dan dapat memainkannya karena media flash card lebih mudah anak-anak untuk belajar dan mudah di ingat. Muridnya yang masih kelompok B menurut ibu guru sangat mudah sekali untuk menggunakan media flash card karena anak tertarik dengan kartu gambar yang di kenalkan oleh ibu gurunya. Muridnya bisa menirukan hurufhuruf, kata dan kalimat yang di sampaikan oleh ibu gurunya.

Hasil obsevasi bahwa media flash card adalah alat bantu guru untuk anak belajar dengan bermain, karena media flash card jenisnya bermacam-macam yaitu kartu gambar buah, binatang, huruf, angka, dll. Media flash card mudah sekali untuk di gunakan dan guru dapat membuatnya sendiri tanpa membeli dengan mahalmahal. Media flash card sangat menarik untuk anak-anak, karena anak dapat merepon dan belajarnya lebih aktif, dari bukti hasil belajar anak-anak dapat berkembang dengan baik sekali. Anakanak mudah mengingat huruf, gambar, angka yang ada di media flash card

Hasil wawancara dan observasi dengan guru dapat di simpulkan bahwa Media flash card adalah alat bantu guru untuk anak bermain dan belajar, medianya sangat menarik sehingga anak dapat merespon anak untuk belajarnya.

c). Wawancara dengan Orang tua

Wawancara dan observasi orang tua, Perkembangan anaknya setelah masuk sekolah sangat berkembang sekali. Anaknya mulai mempunyai rasa tanggung jawab dengan tugas yang di berikan oleh ibu guru untuk mengerjakan tugas di rumah dia langsung mengerjakannya. 
Jurnal Warna : Jurnal Pendidikan Dan Pembelajaran Anak Usia dini. September 2017. Vol 02. No. 02

Semangat belajarnya sangat tinggi dan kalau di rumah suka menirukan gurunya mengajar. Kadang-kadang bermain dengan dengan temannya sukanya bermain sekolah-sekolahan dan faisal yang menjadi gurunya, untuk mengajari teman-temannya. Mamanya melihat anaknya bermain dengan temannya dan apa yang di ajarkan oleh anaknya betul, kemudian mama faisal menanyakan perkembangan faisal di sekolah kepada gurunya. Ibu guru memuji sekali kalau anak didiknya di sekolah anaknya aktif, belajarnya baik dan dapat mengikuti kegiatan belajar yang ada di sekolah.

Observasi orang tua, kebiasaan di rumah kalau anaknya suka bermain sekolah-sekolahan dan menjadi gurunya. Ternyata media yang di gunakan oleh guru sangat merespon anak-anak dan menyenangkan sekali. Hasil wawancara dengan orang tua anak didik ternyata tidak jauh berbeda hasil dari sekolah yang di ajarkan oleh gurunya sangat baik sekali

Hasil wawancara dengan orang tua dan observasi dapat di simpulkan bahwa Media flash card yang digunakan oleh guru di sekolah anak-anak dapat menggunakan juga di rumah dengan teman bermainnya. Hasil dari sekolah yang di ajarkan oleh gurunya sangat baik sekali.

3. Pengembangan Bahasa a). Wawancara dan observasi anak

Wawancara dengan anak Menyebutkan huruf a sampai z dan angkaangka sudah baik sekali, mengulang kembali kata "Nanas, nangka, apel juga sudah bisa. Menirukan kalimat yang di sampaikan oleh ibu guru, contoh ibu pergi ke pasar buah bisa.

Maka hasil obsevasi perkembangan bahasa anak hasilnya baik. Kosa kata : Anak dapat menyebutkan kata-kata dengan jelas, dapat menyebut nama benda yang di perlihatkan dengan benar dan mengulang kembali kosa kata yang baru di dengar juga baik. Melaksanakan 2-3 perintah sederhana, menirukan kembali 3-4 urutan kata dan menirukan kalimat yang di sampaikan juga bisa. Mengemukakan pendapat sederhana dan merespon terhadap pertanyaan juga baik.

Hasil Perkembangan bahasa anak dapat di simpulkan bahwa perkembangan bahasanya baik, anak dapat melaksanakan 2-3 perintah sederhana, dapat menirukan kalimat yang di sampaikan dan dapat merespon terhadap pertanyaan dengan baik.

b). Wawancara dan observasi guru

Wawancara dengan guru, muridnya bisa menirukan huruf-huruf, kata dan kalimat yang di sampaikan oleh ibu gurunya. Anak-anak merespon dari 
Jurnal Warna : Jurnal Pendidikan Dan Pembelajaran Anak Usia dini. September 2017. Vol 02. No. 02

pertanyaan ibu guru Anak dapat menyebutkan kata-kata dengan jelas, dapat menyebut nama benda yang di perlihatkan dengan benar dan mengulang kembali kosa kata yang baru di dengar juga baik.

Observasi guru anak dapat melaksanakan 2-3 perintah sederhana, menirukan kembali 3-4 urutan kata dan menirukan kalimat yang di sampaikan juga bisa. Mengemukakan pendapat sederhana dan merespon terhadap pertanyaan juga baik.

Hasil Perkembangan bahasa, dapat di simpulkan bahwa anak-anak merespon dari pertanyaan ibu guru, anak dapat menyebutkan kata-kata dengan jelas dan kosa katanya baik.

c). Wawancara dan obsevasi orang tua

Wawancara orang tua, anaknya bisa berbicara dengan baik setelah anaknya masuk sekolah, yang awalnya anaknya belum bisa menyebutkan huruf $\mathrm{R}, \mathrm{L}, \mathrm{k}$ sekarang sudah bisa. Menyebutkan kata "Aku" saja, dulu tidak bisa. Di ucapnya "Atu" dan mengucapkan kalimat saja tidak pernah sempurna contoh " Aku sudah selesai belajar" anak berkata "Aku udah selesai berajar".

Observasi orang tua, Semangat belajar anaknya sangat tinggi dan Kebiasaan anaknya jika ada tulisan di televisi, di Koran atau di ajak jalan-jalan oleh papa dan mamanya, dia membaca setiap melihat ada tulisan. Orang tua mengatakan anaknya sangat kritis kalau melihat sesuatu yang menurut dia belum tahu, maka akan tanya sampai jawabannya jelas. Kalau di rumah suka menirukan gurunya mengajar. Kadang-kadang bermain dengan dengan temannya sukanya bermain sekolah-sekolahan dan faisal yang menjadi gurunya, untuk mengajari temantemannya.

Hasil perkembangan bahasa, dapat di simpulkan bahwa anaknya bisa berbicara dengan baik, setelah anaknya masuk sekolah.

\section{PENUTUP}

\section{Kesimpulan}

Berdasarkan hasil wawancara dan observasi anak, guru, orang tua bahwa Media flash card adalah kartu gambar yang menarik, mudah di mainkan sehingga anak dapat merespon dan belajarnya lebih aktif. Media flash card adalah alat bantu guru untuk anak bermain dan belajar, dapat di gunakan juga di rumah dengan teman bermainnya. Hasil dari sekolah yang di ajarkan oleh guru sangat baik sekali sehingga hasil perkembangan bahasa anak baik, anak dapat melaksanakan 2-3 perintah sederhana, dapat menirukan 
Jurnal Warna : Jurnal Pendidikan Dan Pembelajaran Anak Usia dini. September 2017. Vol 02. No. 02

kalimat yang di sampaikan dan dapat merespon terhadap pertanyaan dengan baik.

Perkembangan bahasa anak dapat menyebutkan kata-kata dengan jelas, kosa katanya baik dan bisa berbicara dengan baik setelah anaknya masuk sekolah.

\section{Saran}

Berdasarkan hasil penelitian yang telah diuraikan, maka seluruh perangkat sekolah baik kepala sekolah dan guru menjadi penggerak dalam perbaikan terhadap proses pembelajaran dan membuat anak berminat dan antusias terhadap proses pembelajaran. Apabila kegiatan pembelajaran menggunakan metode bercerita, maka guru sebaiknya menggunakan metode pendukung seperti permainan yang kreatif sehingga lebih termotivasi dan merangsang anak untuk berpikir aktif dan kreatif. Untuk penelitian berikutnya dapat melakuan penelitian yang sama dengan penelitian ini, tetapi dalam bentuk materi dan metode yang berbeda.

\section{DAFTAR PUSTAKA}

Arikunto, Suharsini (2006), Prosedur Penelitian. Jakarta: Rineka Cipta
Brooks, J. B., and D. M. Elliott. Prediction of psychological adjustment at age thirty for leisure time ativities and satisfactions in childhood. Human Development, 1971, 14, 51-61.

Elexmedia. (2009). Falsh card Baby, ( online).(http://elexmedia.co.id/foru $\underline{\mathrm{m}}$ /index.php?topic $=15303.0$.diakses tanggal 5 Mei 2017

Hadi Sutrisno. (2004) metodologi research. Jogjakarta. Pandi

Hardiyanti Eva. 2010. Pengaruh Media Flash Card Terhadap Kemampuan Berbahasa anak kelompok B

Mastija. (2012). Peningkatan kemampuan konsep warna melalui permainan edukatif dengan styrofoam pada anak usia dini Kelompok Adi TK Islam Al Fajar Surabaya. Skripsi tidak diterbitkan. Surabaya:PG PAUD Unesa.

Poerwadarminta,W.J.S. 1976. Kamus Besar Bahasa Indonesia. Jakarta: Balai Pustaka.

Sugiono. (2015). metode penelitian pendidikan. Bandung : Alfabeta

Sriyanto, Pengertian Kemampuan, (23 Desember2010).http://ian43.wordpr ess.com/2010/12/23/pengertiankem ampuan/ 
Jurnal Warna : Jurnal Pendidikan Dan Pembelajaran Anak Usia dini. September 2017. Vol 02. No. 02

Tarigan Henry Guntur. (2008).

Membaca "Ketrampilan

Berbahasa" penerbit angkasa

bandung

Triharso, Agung. (2013). Permainan

Kreatif dan Edukatif untuk Anak

Usia Dini. Jogjakarta: Cv Andi

Wojowasito, S. (1972). Kamus Besar

Bahasa Indonesia. Bandung:

Dharma Shinta. Depdiknas: 2010 